\title{
EFFECTIVENESS OF Bacillus thuringiensis AERIAL SPRAYING AGAINST THE BAGWORM, Metisa plana WALKER (Lepidoptera: Psychidae) OUTBREAK IN OIL PALM USING DRONE
}

\author{
MOHAMED MAZMIRA MOHD MASRI ${ }^{1 *}$; NOORHAZWANI KAMARUDIN'; \\ NUR ROBAATUL MOHD ALI NAPIAH ${ }^{1}$ and MOHD FAHMI KENI ${ }^{1}$
}

\begin{abstract}
Bagworms have been a severe threat to the oil palm industry and have endangered mostly smallholdings. Thus, aerial spraying of Bacillus thuringiensis (Bt) based bioinsecticides using an agricultural drone was carried out to control the bagworm infestation at a severely infested oil palm smallholding located in Sepang, Selangor, Malaysia. The drone was equipped with VP110 nozzle at the pressure of $0.2 \mathrm{MPa}$ with a permanent speed of $2.8 \mathrm{~m} \mathrm{~s}^{-1}$. The flying height was set $2 \mathrm{~m}$ above the canopy. The first round of drone spraying conducted on 4 July 2017 has successfully reduced the larval population of the bagworm, Metisa plana from 304.5 larvae per frond (LPF) at 0 days after treatment (DAT) to 12.1 LPF at 28 DAT, resulting to $96 \%$ reduction in the larval numbers. However, some of the larvae survived to the pupal stage, with approximately 64.52 pupae per frond (PPF) recorded at 28 DAT. The second drone spraying conducted on 27 August 2017 has effectively decreased the larval number from 109.25 LPF at 0 DAT to 9.3 LPF at 28 DAT, resulting in 91.5\% of larvae reduction with zero pupae recorded. The results showed a great potential of drone aerial spraying in controlling bagworms at oil palm planting areas.
\end{abstract}

Keywords: bagworm infestation, biopesticides, drones, unmanned aerial vehicles.

Received: 10 February 2021; Accepted: 26 August 2021; Published online: 23 November 2021.

\section{INTRODUCTION}

In Malaysia, two bagworm species, namely Metisa plana (M. plana) and Pteroma pendula have caused severe yield losses up to $33 \%-47 \%$ in oil palm with $M$. plana being the most economically significant and important defoliator (Basri, 1993; Ramlah et al., 2007a). Bagworm outbreaks have been reported to be more severe in the 1990s until present (Wood and Kamarudin, 2019) in which the infestations had seriously affected the yield of oil palm due to procrastinated and incorrect control strategies

\footnotetext{
Malaysian Palm Oil Board,

6 Persiaran Institusi, Bandar Baru Bangi,

43000 Kajang, Selangor, Malaysia.

* Corresponding author e-mail: mazmira@mpob.gov.my
}

(Tey and Cheong, 2013). The outbreaks of these leaf-eating caterpillars which brings about severe losses to the oil palm industry therefore need to be prevented (Norman and Mazmira, 2019). The invasion of these leaf eating pests has affected the majority of oil palm smallholders, making it a national concern (Thomas, 2017). In 2017, more than 30000 ha of oil palm smallholdings was infested by bagworm (Kamarulbaid, 2018). The recurrence of the bagworm outbreak in the oil palm industry has therefore contributed to severe economic losses of more than USD25 million annually, and urgent control measures should be undertaken. Without proper control, severely attacked palms can suffer high crop loss, which futher affect the livelihoods of oil palm planters, especially the smallholders. On 15 November 2013, under the Malaysia Act 167 (Plant 
Quarantine Act 1967), the Malaysian government declared bagworm as a dangerous pest (Kamarudin et al., 2017). Under the Plant Quarantine Act 1967, any plantation owner or smallholder who fails to take action in controlling the bagworm infestation will be penalised not more than RM10 000 or jail for two years (Attorney General's Chambers, 2013).

Control measures using chemical insecticides application have been widely conducted in plantations compared to smallholdings (Hasber, 2010). The application of broad-spectrum chemical insecticides such as cypermethrin will cause a direct effect in reducing the population of natural enemies (parasitoid and predators) of the bagworms, hence, increasing the risk of an outbreak (Norman and Mazmira, 2019). Biological control developed from natural agents that provides long term control of the bagworm outbreak. Aerial spraying using a Bacillus thuringiensis $(\mathrm{Bt})$ is one of the viable approaches for controlling bagworms in oil palm. Bt is an environmentally friendly microbial insecticide and does not cause harm to freshwater fish and other living organisms (Ahmad et al., 2014; 2015).

Usage of aircraft for aerial spraying is one of the best strategies to control a large outbreak area. In China, agricultural aerial spraying effectively ensures that food and ecological security is achieved (Zhang et al., 2018). In Malaysia, an aerial spraying operation carried out in Slim River, Perak for controlling $M$. plana has successfully reduced the overall population of bagworms to below the threshold level (Kamarudin et al., 2017). However, usage of agricultural aircraft has many challenges, including the aircraft's technical issues, availability of airstrips and permit approvals from the Civil Aviation Authority of Malaysia (CAAM) and Department of Agriculture (DOA) which may cause delays in controlling the bagworm outbreaks. An agricultural aircraft had crashed during aerial spraying of Bt for bagworm control in Pahang on 25 February 2018 due to technical issues (Amin, 2018).

In order to reduce the dependence on agricultural aircraft, the focus has now been shifted to the usage of lightweight, unmanned aerial vehicles (UAVs), commonly known as drones. Drones are remote-controlled aircrafts with no human pilots on board. Drones have a huge potential in supporting evidence-based planning and in spatial data collection. Most applications of drone technology depend on their ability to generate and deliver accurate information (European Commission, 2018). Despite some intrinsic restrictions, these tools and technologies can deliver valuable data that can then be used for control strategies and making vital decisions. Drones are usually operated remotely by telemetry through autonomous flight along preprogrammed paths using global positioning system (GPS) or visual contact by the operator (Giles and
Billing, 2015). The first uses of drones in agriculture have mostly focussed on remote sensing and visual inspection of crop or field surroundings. In the present era, drone application has been widely used in agriculture and serves as an alternative to manned aircraft. Drones have also assisted in the technical analysis for precision agriculture, such as crop monitoring and crop height where it was found that UAV increased the productivity of spraying activity and optimised the usage of water and chemicals (Rao Mogili and Deepak, 2018). A study by Giles and Billing (2015) shows that UAV was successfully utilised in a vineyard spraying operation where the workload reached up to 50 litre ha $^{-1}$ with a coverage of between 2-5 ha hr-1. UAV technology has also shown substantial improvements in crop scouting, yield and field boundary mapping, pest control and spraying. UAVs which can also be deployed promptly and repeatedly, are safer than aircraft, and have flexible timing of missions.

Paddy monitoring using a multirotor UAV and RGB digital camera in Kelantan was reported by Norasma (2018). Mat Su et al. (2018) reported that aerial spraying using a drone is comparable to knapsack spraying with coefficient values (CVs) of 0.46 and 0.43 , respectively, with uniformity of spraying at $2 \mathrm{~m}$ height. The Muda Agricultural Development Authority (MADA) has also carried out commercial chemical pesticide spraying using drones on 2000 ha of paddy (Bernama, 2017). Nevertheless, no technical paper has been published on UAV operation and efficacy. Besides paddy, no other crops have been reported to utilise drone technology for aerial spraying.

The potential of aerial spraying using drones in the oil palm industry is enormous, especially for controlling oil palm pests such as bagworms. The objective of this research was to determine the effectiveness of aerial spraying of Bt using drones against the bagworm, $M$. plana in oil palm plantation.

\section{METHODOLOGY}

\section{Bacillus Thuringiensis (Bt) Based Biopesticides for the Aerial Spray Activity}

Bt was mass-produced using liquid-state fermentation and laboratory prepared medium at Malaysian Palm Oil Board (MPOB) Microbial Technology and Engineering Centre (MICROTEC) in 5-500 litres bioreactors (Sartorius Stedim, Germany) for $48 \mathrm{hr}$, at $30^{\circ} \mathrm{C}$ (Ahmad et al., 2012). The mass production of microbial insecticide based on local isolates known as MPOB Bt1 for controlling bagworm has been patented (Patent No. PI2011000307) (Ramlah et al., 2011). Ecobac-1 (EC) is an emulsified product derived from an 
indigenous strain of Bt (MPOB Bt1) (Ramlah and Basri, 1997). The active ingredients of EC are spores and $\delta$-endotoxins, standardised to $1600 \mathrm{IU} \mathrm{mg}^{-1}$.

\section{The UAV (Drone) System and Specifications}

The drone used for the spraying operation was JMR V1650 measuring $1650 \mathrm{~mm}$ in diagonal length (Figure 1). The drone was powered by a twin pack of $22000 \mathrm{mAh} 22.2 \mathrm{~V}$ lithium polymer battery connected in series and can carry a payload of up to 20 litres of pesticides. The maximum take-off weight is $38 \mathrm{~kg}$ and it can fly with a full payload for around 10-13 min. With the arms fully extended, the spraying width can go up to $8 \mathrm{~m}$. With a total of four nozzles, the biopesticide can be sprayed at 1.8 litre $\mathrm{min}^{-1}$. The flying height of the drone during spraying, was at 2-3 $\mathrm{m}$ from the palm canopy for better droplet distribution on the palm leaves. Other specifications of the drone as listed in Table 1.

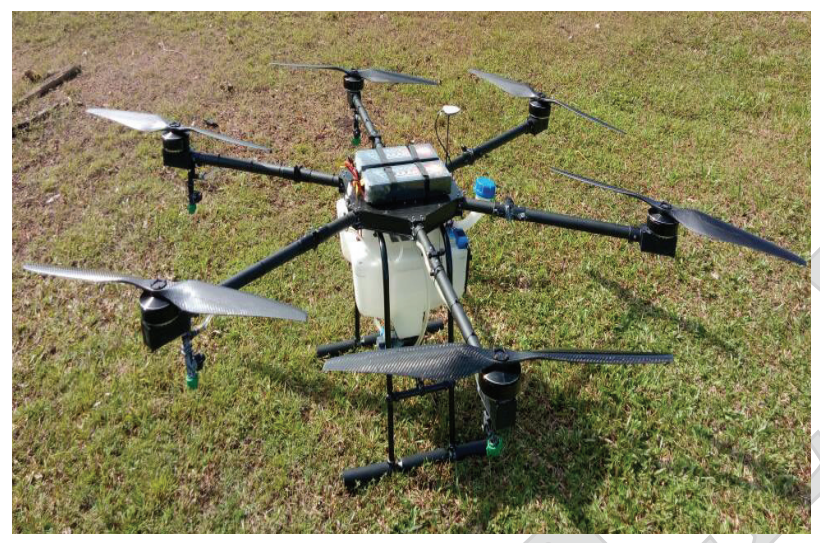

Figure 1. The drone, JMR V1650 used for the aerial spraying operation.

TABLE 1. SPECIFICATIONS OF THE DRONE, JMR-V1650 FOR THE SPRAYING OPERATION OF BAGWORM

\begin{tabular}{|c|c|}
\hline Parameters & Value/ information \\
\hline Solution v & 15 litres \\
\hline Nozzle model & VP 110015 \\
\hline Pump pressure & $0.2 \mathrm{MPa}$ \\
\hline Flc & $\begin{array}{l}1.8 \text { litre } \mathrm{min}^{-1} \\
\left(0.45 \text { litre } \mathrm{min}^{-1} \text { x } 4 \text { nozzles }\right)\end{array}$ \\
\hline Working flight speed & $1.9-2.2 \mathrm{~m} \mathrm{~s}^{-1}$ \\
\hline Spray operation time & $8-10 \mathrm{~min}$ \\
\hline Flying height & 2-3 m above canopy \\
\hline Area covered & 0.5 ha \\
\hline Bt application rate & 30 litre ha ${ }^{-1}$ \\
\hline Bt rate & 1.5 litre ha ${ }^{-1}$ \\
\hline Flight mode & ATT/Spray work/GPS \\
\hline Maximum flight height & $30 \mathrm{~m}$ (for automated operation) \\
\hline Flight operation time & $\begin{array}{l}20 \text { min maximum } \\
\text { (take-off to landing) }\end{array}$ \\
\hline Control distance & $1000 \mathrm{~m}$ maximum \\
\hline
\end{tabular}

\section{Sprayer Module}

The $110^{\circ}$ fan nozzle nozzle size was $0.4 \mathrm{~mm}$ (110 $0.15 \mathrm{VP})$. The distance between the two nozzles was $50 \mathrm{~cm}$. The variable pressure nozzle maintains a consistent spray angle over a wide pressure range, up to 20 psi ( 1 bar) and is available in $80^{\circ}$ and $110^{\circ}$ versions to work with different boom heights. At $0.2 \mathrm{MPa}$, the flow rate is at 0.45 litre $\mathrm{min}^{-1}$. A total of 0.5 ha area was covered for each flight with working flight speed ranging from $1.9-2.2 \mathrm{~m} \mathrm{~s}^{-1}$ and solution volume of 15 litres. The volume application rate was 30 litre $\mathrm{ha}^{-1}$ at a biopesticide rate of 1.5 litre $\mathrm{ha}^{-1}$. The detailed specification of the spraying is as shown in Table 1 .

\section{Drone Spraying Field Operation}

The first drone spraying was conducted against the susceptible first to fourth larval instars of M. plana at Kg. Simpang Morib, Selangor, Malaysia smallholdings on 4 July 2017. The drone spraying was scheduled based on the life cycle of the bagworm. The average life cycle for M. plana from eggs to adults takes approximately 103.5 days (Kok et al., 2011). Due to the multi-stage infestation of bagworms in the area, some larvae had survived to the pupal stage at 28 days after treatment (DAT). Hence, the second round of drone spraying was carried out on 27 August 2017. The infested area was GPS-mapped (Figure 2) and sprayed with 0.75 litres EC diluted in the drone tank using 15 litres of water. The total area sprayed was 5.56 ha. In both aerial spraying operations, an adjacent area without any treatment was set up as a control plot.

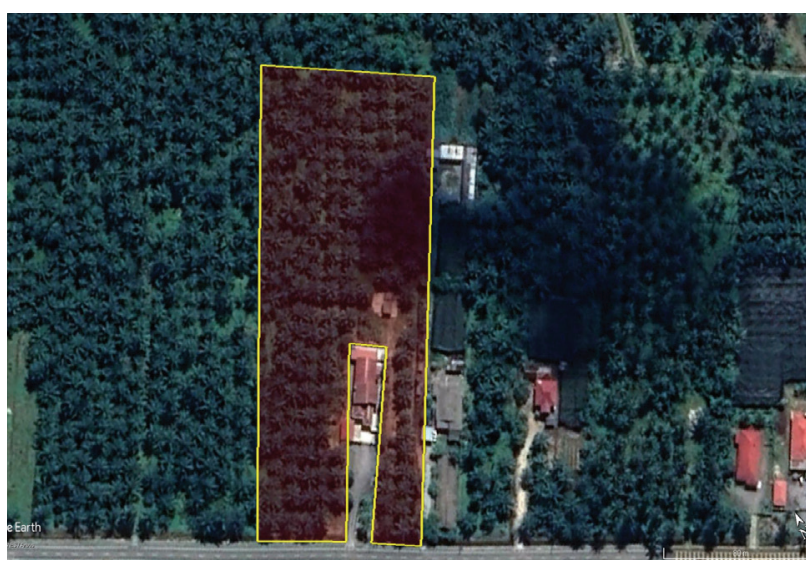

Figure 2. Aerial map of the oil palm smallholdings in Sepang affected by bagworm.

\section{Bagworms Census}

A pre-census of the bagworm population was conducted before aerial spraying operation to count and record the initial bagworm population. 
Post-census counts of the bagworm populations were conducted at 7, 14 and 28 DAT. One percent of the infested area was censused by taking one palm at every $10^{\text {th }}$ palm at every $10^{\text {th }}$ row. Frond number 17 from the middle of the canopy showing fresh damage symptoms was cut down for counting, and the number of larvae and pupae on both sides of the frond was recorded (MPOB, 2016). The control procedures must be conducted once the eggs within the female pupal bags hatch into early larval stages (Norman et al., 2004; Ramlah et al., 2007a; 2007b). Control measures should start immediately when the larval population is at the early instar stages (first to fourth larval instars), and the number is above the threshold level [5-10 larvae per frond (LPF)] (Wood, 2002). If more than $70 \%$ of the population are at the late instars (fifth to seventh larval instars) or pupal stages, the aerial spray using Bt must be postponed (Basri, 1993; Ramlah et al., 2007a; 2007b). The aerial spray would then be carried out on the next generation of M. plana once the early larval stages emerge.

\section{Water Sensitive Paper (WSP) Location and Droplet Distribution}

Spray droplets were determined using WSP during each operation. WSPs were placed on rectangular wooden boards attached to a pole in the middle of the harvesting path. The heights of the poles were adjusted to match the heights of the oil palm trees (MPOB, 2016). One pole was divided into three levels with $1.0 \mathrm{~m}$ space for each level beginning from the same level with oil palm height, and each level was placed with four WSP for a total of 12 WSPs per pole (Figure 3). One pole was positioned at every 30 ha of the target area. These WSPs would indicate and ensure that the biopesticides mist is well distributed during the spraying operation. After every spraying operation, the WSPs will be collected immediately. After the droplets dried, the WSP was placed in marked envelopes, stored in sealed dry plastic bags and transferred to the laboratory for further analysis. The DropLeaf app was used to analyse and calculate the droplet distribution on WSPs. The volume median diameter (VMD) was also analysed in the first and second round of the aerial sprayings. VMD stands for midpoint droplet size (median), where half of the spray volume is in smaller droplets and half of the volume is in bigger droplets.

\section{Data Analysis}

Data on the field survival of bagworms treated with the Bt1 product was analysed using twoway analysis of variance (ANOVA) (Sigma-plot version 12.5) with the main factor was treatment plot (Bt treatment plot and control plot) and subfactor was the DAT interval $(0,7,14,21$ and 28 DAT). The means were separated using the Tukey comparison test. The time course population dynamics of the different stages of bagworms was closely monitored for precision in follow-up sprays.

\section{RESULTS}

\section{Bagworm Mortality During the First Round of Drone Spraying}

The application of drone aerial spraying for controlling multi-stage bagworm outbreaks was carried out in the hotspot area at an oil palm smallholding in Sepang, Selangor, Malaysia. The first round of drone spraying had commenced on 4 July 2017. At 0 DAT, the data showed that the

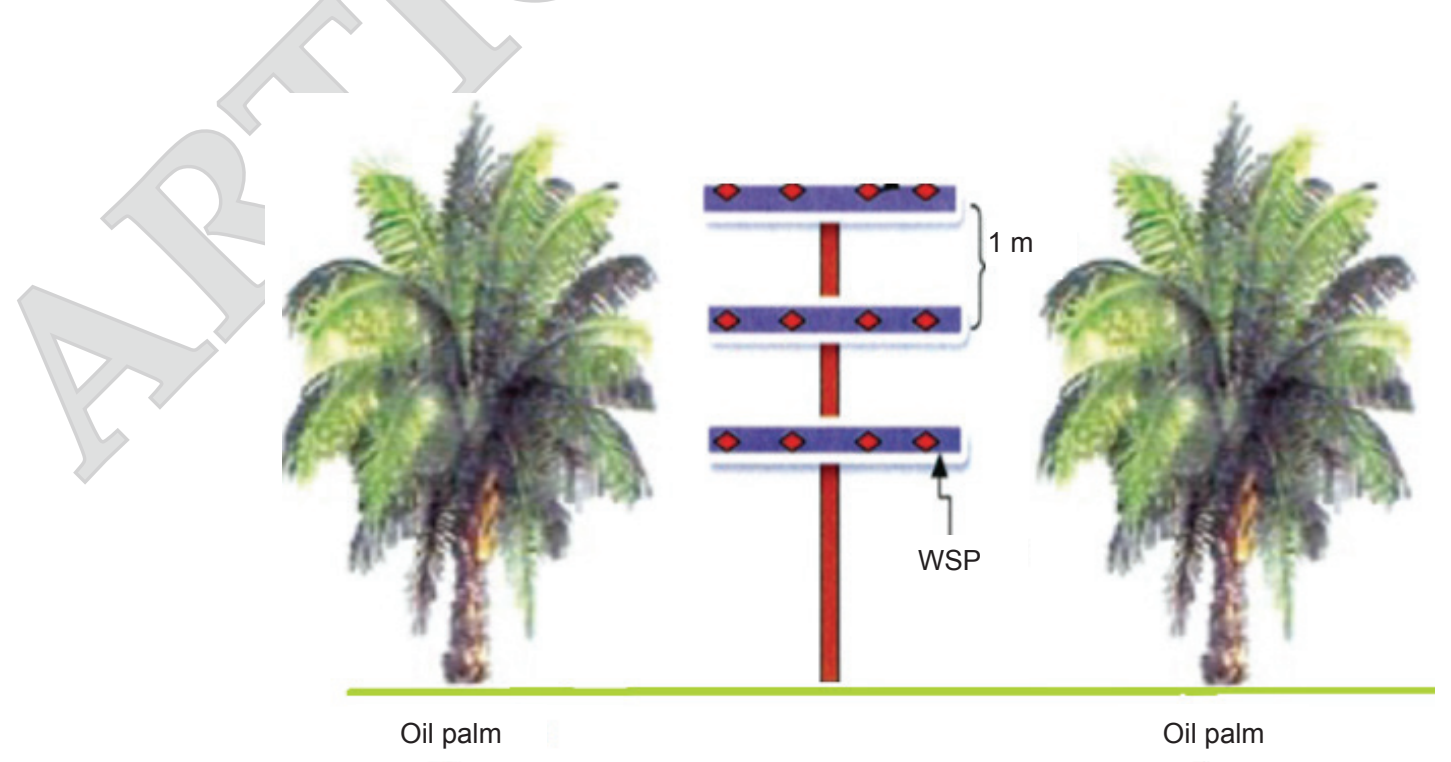

Figure 3. The position of the pole with WSP during the aerial spraying. 
overall mean LPF was 304.5, with the majority of the larvae at larval instars 3 (L3) (Table 2). The mean population of mature larvae (L4 and L5) was approximately 117.7 and $25.5 \mathrm{LPF}$, respectively. The high number of mature larvae indicated that there was a high probability of the population surviving the treatment once it entered the pupal stage. Seven days after the treatment, the percentage of larval reduction recorded was moderate $(30.6 \%)$ with the overall average of 211.2 LPF. Significant reduction in the mean larval population was recorded starting at 14 DAT, where the pooled average larval population decreased from 304.5-149.9 LPF (Table 2) which was $50.7 \%$ reduction in larval population.

Larval reduction was further recorded at 21 DAT with an overall mean of $74.7 \mathrm{LPF}$ or $75.5 \%$ in larval reduction. At $28 \mathrm{DAT}$, the overall mean of larval population had decreased substantially to 12.1 LPF with $96 \%$ reduction in larval population. Although the overall mean of LPF recorded at
28 DAT was small, the overall mean pupae per frond (PPF) was significantly high at 64.5 PPF. The data showed that drone spraying using Bt has effectively reduced the number of larvae; however, due to the severe and multi-stage infestation in the area, some of the mature larvae had managed to enter the pupa stage. Thus, repetition of treatment was required to control the second generation of bagworms from the survived pupae.

In contrast, the bagworm population in the untreated control plot recorded a high population of the total mean number of bagworms ranging from 131 bagworms per frond (BPF) at 0 DAT to $137 \mathrm{BPF}$ at 28 DAT (Table 3). There was no reduction of the total bagworm number in the control plot due to natural factors because the area was concomitantly being attacked by multi-stage bagworm infestation. The total mean number of bagworms recorded in the control plot maintained above the economic injury threshold level until 28 DAT.

TABLE 2. EFFECT OF ECOBAC-1 (EC) AGAINST BAGWORM SURVIVAL BEFORE AND AFTER THE FIRST ROUND OF DRONE SPRAY

\begin{tabular}{lccccc}
\hline \multirow{2}{*}{ Bagworm stage } & $\begin{array}{c}\text { 0 DAT } \\
\mathbf{( 4 / 7 / 1 7 )}\end{array}$ & $\begin{array}{c}\text { 7 DAT } \\
\mathbf{( 1 0 / 7 / 1 7 )}\end{array}$ & $\begin{array}{c}\text { 14 DAT } \\
(\mathbf{1 7 / 7 / 1 7 )}\end{array}$ & $\begin{array}{c}\text { 21 DAT } \\
\mathbf{( 2 4 / 7 / 1 7 )}\end{array}$ & $\begin{array}{c}\text { 28 DAT } \\
\mathbf{( 3 1 / 7 / 1 7 )}\end{array}$ \\
\cline { 2 - 6 } & \multicolumn{5}{c}{ Mean \pm SE } \\
\hline L1 & 0 & 0 & 0 & 0 & 0 \\
L2 & $38.62 \pm 2.9$ & 0 & 0 & 0 & 0 \\
L3 & $122.72 \pm 10.0$ & $37.3 \pm 3.0$ & 0 & 0 & 0 \\
L4 & $117.7 \pm 10.7$ & $74.34 \pm 6.8$ & $19.08 \pm 1.2$ & 0 & 0 \\
L5 & $25.46 \pm 4.2$ & $73.74 \pm 6.7$ & $60.14 \pm 2.6$ & $14.62 \pm 1.6$ & 0 \\
L6 & 0 & $25.82 \pm 2.9$ & $54.66 \pm 2.5$ & $25.6 \pm 2.0$ & $1.8 \pm 0.2$ \\
L7 & 0 & 0 & $16.1 \pm 1.2$ & $34.52 \pm 2.0$ & $10.3 \pm 0.8$ \\
Overall mean pupae (per frond) & 0 & 0 & 0 & $11.74 \pm 1.2$ & $64.52 \pm 2.2$ \\
Overall mean larvae (per frond) & $304.5 \pm 21.4^{\mathrm{a}}$ & $211.2 \pm 15.0^{\mathrm{b}}$ & $149.98 \pm 6.0^{\mathrm{c}}$ & $74.74 \pm 4.5^{\mathrm{d}}$ & $12.1 \pm 0.8^{\mathrm{e}}$ \\
Overall mean bagworm (per frond) & $304.5 \pm 21.4^{\mathrm{a}}$ & $211.2 \pm 15.0^{\mathrm{b}}$ & $149.98 \pm 6.0^{\mathrm{c}}$ & $86.48 \pm 4.9^{\mathrm{d}}$ & $76.62 \pm 2.6^{\mathrm{e}}$ \\
\% Larvae reduction & - & 30.6 & 50.7 & 75.5 & 96 \\
\% Bagworm reduction & - & 30.6 & 50.7 & 71.6 & 74.8 \\
\hline
\end{tabular}

Note: $\mathrm{L}$ indicates bagworm larval instars. Mean with the same letters in the same row are not significantly different by Tukey comparison test $(\mathrm{p}<0.001)$.

TABLE 3. COMPARISON OF THE TOTAL MEAN NUMBER OF BAGWORM IN THE CONTROL AND Bt TREATMENT PLOT DURING THE FIRST ROUND OF DRONE SPRAY

\begin{tabular}{lccc}
\hline & Time (DAT) & \multicolumn{2}{c}{ Total bagworm per frond (BPF) } \\
\cline { 3 - 4 } No. of bagworm (Mean \pm SE) & 0 & Control plot & Bt treated plot \\
\hline & 7 & $131.06 \pm 3.83 \mathrm{Ac}$ & $304.5 \pm 21.4 \mathrm{Ba}$ \\
& 14 & $133.40 \pm 2.62 \mathrm{Ac}$ & $149.98 \pm 6.0 \mathrm{Bc}$ \\
& 21 & $137.16 \pm 2.45 \mathrm{Ac}$ & $86.48 \pm 4.9 \mathrm{Bd}$ \\
\hline
\end{tabular}

Note: Means that do not share a capital/small letter in the table are significantly different.

Tukey simultaneous test at 95\% confidence levels. 


\section{Bagworm Mortality During the Second Round of Drone Spraying}

The second round of drone spraying was carried out on 27 August 2017. At 0 DAT, overall mean recorded was 109.3 LPF. Majority of the larvae were still at L1 and L2, whilst none were recorded from L3 to L7. There were no pupae recorded at 0 DAT. Similar to the first drone spraying, the percentage of larval reduction at 7 DAT was recorded under 50\%, which was only $27.5 \%$ reduction (Table 4 ). The overall mean recorded was 79.2 LPF. A significant reduction in the bagworm population was recorded at 14 DAT. The percentage of larval reduction recorded at 14 DAT was more than $50 \%$ with an overall mean of 52.6 LPF. The overall mean of LPF kept decreasing at 21 DAT with 25.3 LPF and 76.8\% larval reduction. Eventually, at 28 DAT, the larval population was recorded under the threshold level with only 9.3 LPF. The final percentage of larvae reduction at 28 DAT was $91.5 \%$. No pupae were recorded at 28 DAT. With the right strategy, the drone spraying had successfully controlled the bagworm outbreak in just two rounds of drone spraying application.

In the control plot, the total mean number of bagworms had increased tremendously after more than a month left untreated. At 0 DAT, the total mean was $472 \mathrm{BPF}$, almost three times higher than the number recorded at 28 DAT in the control plot during the first drone aerial spray (Table 5). The bagworm number increased to $501 \mathrm{BPF}$ at $28 \mathrm{DAT}$, severely damaging the oil palms in the area. The data clearly showed that if the bagworm attack was left untreated as in the control plot, the bagworm population will keep increasing and will severely affect the oil palm trees.

The unequal number of bagworm populations in the control and treated plots in the zero-day for the first spray was due to the selection of control plot that had low bagworm population to avoid severe effects at that area. Due to no treatment at the control plot, the bagworm population was different compared to the treated area in the zero-days for the second spray.

TABLE 4. EFFECT OF ECOBAC-1 (EC) AGAINST BAGWORM SURVIVAL BEFORE AND AFTER THE SECOND ROUND OF DRONE SPRAY

\begin{tabular}{|c|c|c|c|c|c|}
\hline \multirow[t]{2}{*}{ Bagworm stage } & $\begin{array}{c}\text { 0 DAT } \\
\text { (27/8/17) }\end{array}$ & $\begin{array}{l}7 \text { DAT } \\
\text { (5/9/17) }\end{array}$ & $\begin{array}{l}\text { 14 DAT } \\
\text { (11/9/17) }\end{array}$ & $\begin{array}{l}21 \text { DAT } \\
\text { (18/9/17) }\end{array}$ & $\begin{array}{l}28 \text { DAT } \\
(25 / 9 / 17)\end{array}$ \\
\hline & \multicolumn{5}{|c|}{ Mean \pm SE } \\
\hline L1 & $35.25 \pm 0.91$ & 0 & 0 & 0 & 0 \\
\hline L2 & $74 \pm 2.27$ & $23.35 \pm 2.32$ & 0 & 0 & 0 \\
\hline L3 & 0 & $52.8 \pm 2.62$ & $12.65 \pm 0.91$ & 0 & 0 \\
\hline L4 & 0 & $3.05 \pm 0.74$ & $32.5 \pm 1.35$ & $5.75 \pm 0.53$ & 0 \\
\hline L5 & & 0 & $7.45 \pm 0.82$ & $17.2 \pm 0.73$ & $1.4 \pm 0.18$ \\
\hline L6 & & 0 & 0 & $2.35 \pm 0.40$ & $6.65 \pm 0.18$ \\
\hline L7 & 0 & 0 & 0 & 0 & $1.25 \pm 0.19$ \\
\hline Overall mean pupae (per frond) & 0 & 0 & 0 & 0 & 0 \\
\hline Overall mean larvae (per frond) & $109.25 \pm 2.87^{\mathrm{a}}$ & $79.2 \pm 4.41^{\mathrm{a}}$ & $52.6 \pm 2.56^{\mathrm{b}}$ & $25.3 \pm 0.71^{\mathrm{c}}$ & $9.3 \pm 0.28^{\mathrm{d}}$ \\
\hline Overall mean bagworm (per frond) & $109.25 \pm 2.87^{\mathrm{a}}$ & $79.2 \pm 4.41^{\mathrm{a}}$ & $52.6 \pm 2.56^{\mathrm{b}}$ & $25.3 \pm 0.71^{\mathrm{c}}$ & $9.3 \pm 0.28^{\mathrm{d}}$ \\
\hline$\%$ Larvae reduction & - & 27.5 & 51.9 & 76.8 & 91.5 \\
\hline$\%$ Bagworm reduction & - & 27.5 & 51.9 & 76.8 & 91.5 \\
\hline
\end{tabular}

Note: $\mathrm{L}$ indicates bagworm larval instars. Mean with the same letters in the same row are not significantly different based on Tukey comparison test $(\mathrm{p}=<0.001)$.

TABLE 5. COMPARISON OF THE TOTAL MEAN NUMBER OF BAGWORM IN THE CONTROL AND Bt TREATMENT PLOT DURING THE SECOND ROUND OF DRONE SPRAY

\begin{tabular}{lccc} 
& & & \multicolumn{2}{c}{ Total bagworm per frond (BPF) } \\
& Time (DAT) & Control plot & Bt treated plot \\
\cline { 3 - 4 } No. of bagworm (Mean \pm SE) & 0 & $472.30 \pm 5.60 \mathrm{Ab}$ & $109.25 \pm 2.87 \mathrm{Bc}$ \\
& 7 & $468.40 \pm 2.10 \mathrm{Ab}$ & $79.2 \pm 4.41 \mathrm{Bd}$ \\
& 14 & $469.55 \pm 1.10 \mathrm{Ab}$ & $25.3 \pm 0.71 \mathrm{Bf}$ \\
\hline
\end{tabular}

Note: Means that do not share a capital/small letter in the table are significantly different.

Tukey simultaneous test at 95\% confidence levels. 


\section{Droplets Distribution}

The quality of spray application in the field is usually measured by WSPS or Kromekote ${ }^{\circledR}$ card attached to selected target areas or leaves and inspected after the spraying operation (Sundaram et al., 1987; Theriault et al., 2001). The results will indicate the average amount of droplets deposited according to the flight height and velocity contributed during the drone spraying operation. In the current study, the droplets had distributed uniformly on the leaves. The average droplet deposition and uniformity of each spraying operation were as shown in Figure 4. During the first round of spraying, the droplets characteristics were sparse while in the second round of spraying the droplets were slightly denser (Figure 4). Each pole consists of six WSPs. The number of droplets on each WSP card was analysed using DropLeaf apps. The average number of spray droplets deposited on the WSPs for the first-round sprays were 10-20 droplets $\mathrm{cm}^{-2}$ with VMD range of 710$774 \mu \mathrm{m}$ while the second rounds sprays were 27.43-41.29 droplets $\mathrm{cm}^{-2}$ with VMD range of 732-790 $\mu \mathrm{m}$ (Table 6). Syngenta Crop Protection AG (Basel, Switzerland) recommends at least
20-30 droplets $\mathrm{cm}^{-2}$ for insecticide or pre-emergence herbicide applications, 30-40 droplets $\mathrm{cm}^{-2}$ for contact post-emergence herbicide applications, and 50-70 droplets $\mathrm{cm}^{-2}$ for fungicide applications to provide satisfactory results.

The droplets deposition during both operations showed that medium layer (ML) and bottom layer (BL) of WSP for both rounds captured less droplets compared to upper layer (UL) WSPs. Based on the bagworm census, it was found that the droplets uniformity is a good indicator or guide to evaluate the efficacy of the aerial spraying (Guo et al., 2019). The results also indicated that the flight height and velocity established in this operation was apposite for the uniform deposits of the droplets observed on the oil palm leaves.

\section{Effect of Rainfall on Drone Spraying Efficacy and Bagworm Mortality}

During the first round of drone spraying, rainfall was recorded at 3 DAT $(6.6 \mathrm{~mm})$, and the situation continued for three more days, with an average rainfall of $23.2 \mathrm{~mm}, 1.9 \mathrm{~mm}$ and $24.5 \mathrm{~mm}$, respectively (Figure 5). The highest rainfall (35.1 $\mathrm{mm}$ ) was recorded at 10 DAT. Beginning 12 DAT,
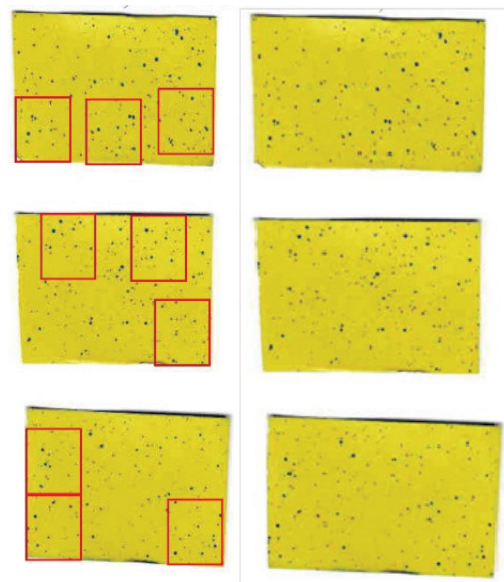

a
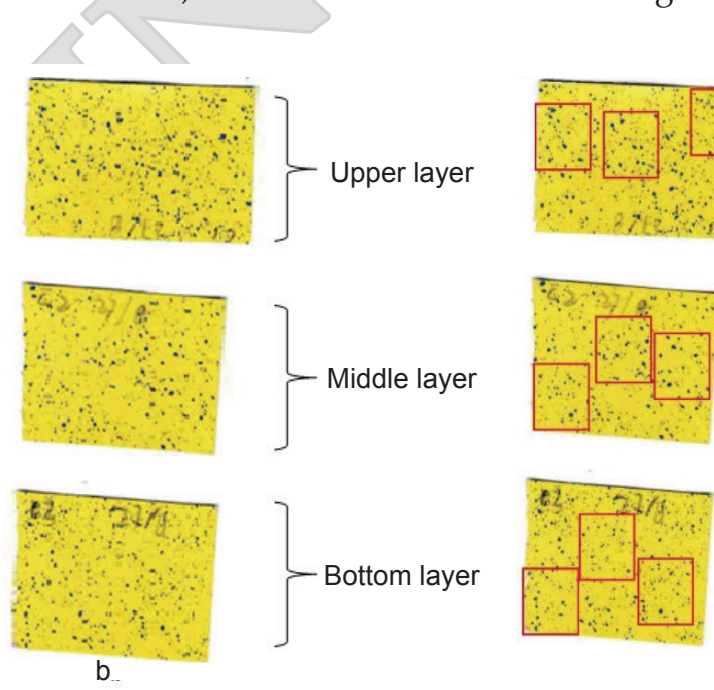

Figure 4. Droplet depositions on WSP placed on a pole at oil palm plantation during the drone spraying. (a) first round of drone spraying, and (b) second round of drone spraying.

TABLE 6. SUMMARY OF WSP SPRAY COVERAGE AT THREE POSITIONS IN THE CANOPY (UPPER, MIDDLE AND BOTTOM) AT TWO ROUNDS OF SPRAYS

\begin{tabular}{llccc}
\hline & & Upper & Middle & Bottom \\
\hline First round spray & WSP coverage area $(\%)$ & 98.61 & 98.09 & 98.98 \\
& Droplets cm ${ }^{-2}$ & 20 & 15.86 & 10 \\
& VMD $(\mathrm{Dv} 0.5 \mu \mathrm{m})$ & 714.52 & 774.15 & 710.84 \\
\multirow{2}{*}{ Second round spray } & WSP coverage $(\%)$ & 97.49 & 97.47 & 97.04 \\
& Droplets cm ${ }^{-2}$ & 41.29 & 32.14 & 27.43 \\
& VMD $(\mathrm{Dv} 0.5 \mu \mathrm{m})$ & 732.46 & 764.56 & 790.79 \\
\hline
\end{tabular}


no rainfall was recorded until 28 DAT. Based on the results, it appears that rainfall did not significantly affect the drone spraying efficacy in controlling the bagworm population. The untimely rainfall only after 3 DAT and high rainfall at 10 DAT did not washout the Bt droplets on the leaves as the larval population kept decreasing until 28 DAT.

Heavy rainfall was recorded at 4 DAT (74.8 $\mathrm{mm}$ ) during the second round of aerial spraying. The second highest rainfall was recorded on 15 DAT with $48.9 \mathrm{~mm}$. Unlike the first drone spraying, heavier rainfalls $(>40 \mathrm{~mm})$ occurred twice in the second drone spraying operation (Figure 6). Besides at 4 and 15 DATs, other days from 0 to 28 DATs in the second round of drone spraying operation recorded an average rainfall ranging from 0.6-16.6 $\mathrm{mm}$. However, similar to the first drone spraying operation, the rainfalls did not significantly affect the bagworm mortality with the reduction of larval population recorded at 28 DAT had exceeded $90 \%$. Based on the results in the first and second round of drone sprayings, average rainfalls $(20-40 \mathrm{~mm})$ and heavy rainfall $(>40 \mathrm{~mm})$ did not cause significant Bt products washout as the larval population kept plummeting until 28 DAT.

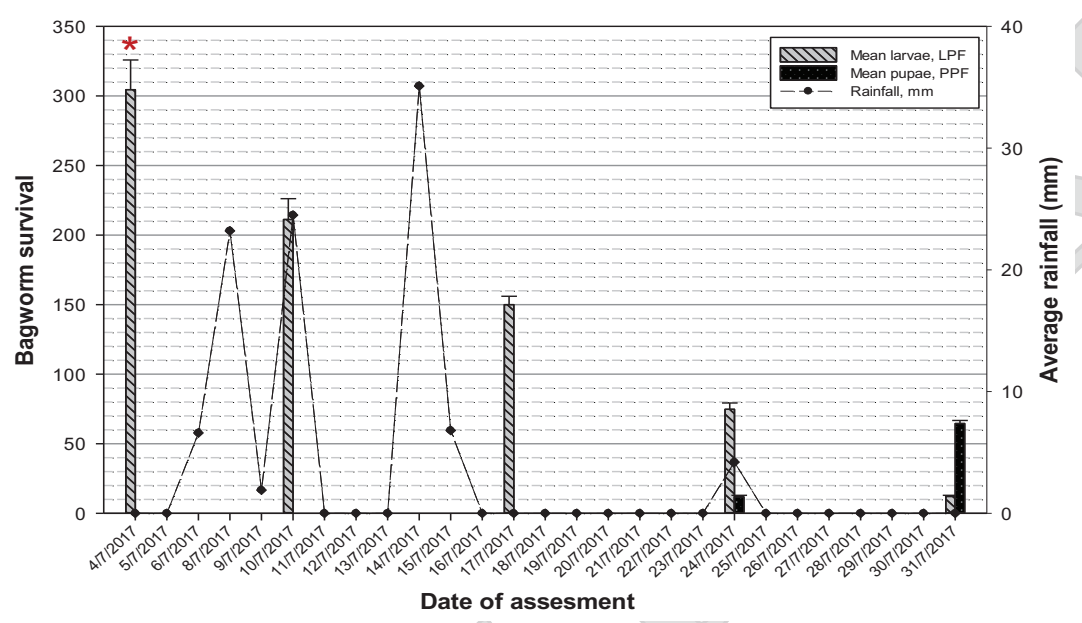

Note: Number of aerial sprays was based on bagworm's population generation; spraying was conducted on 4 July 2017 as indicated by star*. The total sprayed area was $5.56 \mathrm{ha}$.

Figure 5. Average larvae and pupae population of $\mathrm{M}$. plana after the first round of drone spraying at smallholding area in Banting, Selangor, Malaysia.

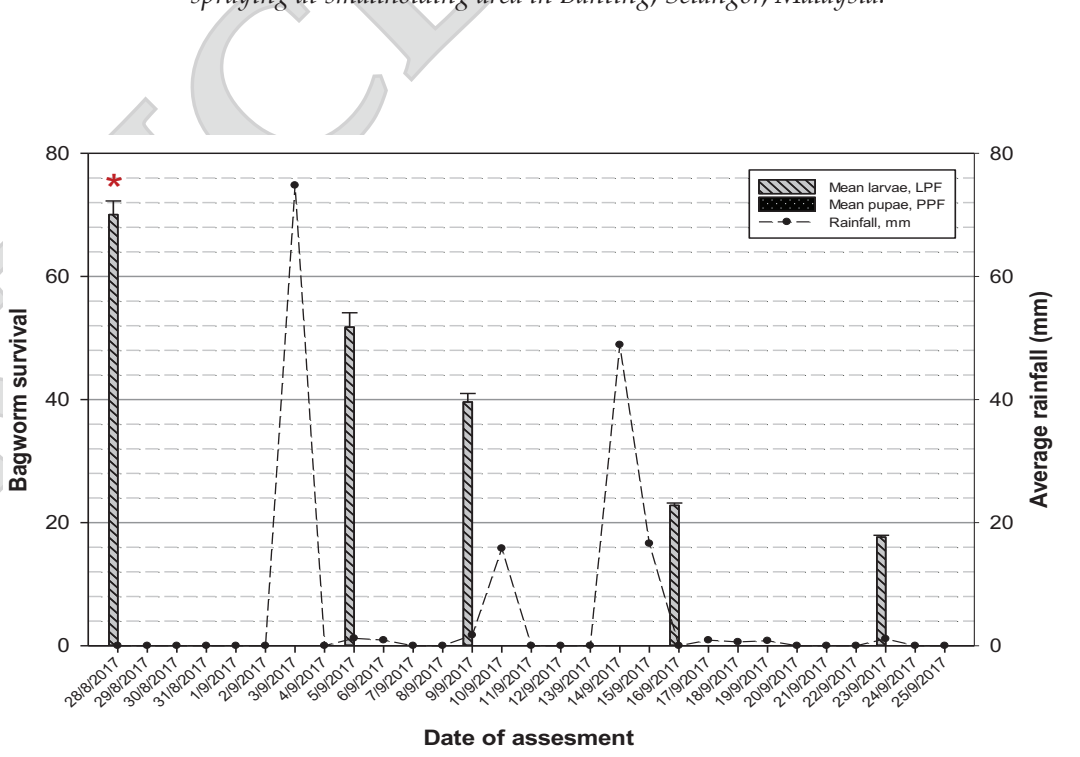

Note: Number of aerial sprays was based on bagworm's population generation; spraying was conducted on 27-28 August 2017 as indicated by star*. The total sprayed area was 5.56 ha.

Figure 6. Average larvae and pupae population of M. plana after the second round of drone spraying at smallholding area in Banting, Selangor, Malaysia. 


\section{Post-census After the Drone Spraying}

The condition of the smallholding areas was reassessed in December 2019 which was more than two years after the drone sprayings were carried out in July and August 2017. The oil palms conditions have significantly recovered and appeared healthier compared to the conditions recorded in July 2017. The scorched-like area, which was recorded in 2017, has completely changed to a lush green area (Figure 7). Besides aerial monitoring using drones, the monitoring was also carried out through ground inspection. Based on the census data, the population of bagworm larvae in the area was below the economic threshold level ( $<10$ LPF). Hence, control is not required. Observation from the ground reconfirmed the aerial view finding where the oil palms looked healthy and had fully recovered from the previous outbreak (Figure 8).

\section{DISCUSSION}

In this study, we have demonstrated the effectiveness of drone aerial spraying using $\mathrm{Bt}$ for the control of bagworms at a severely, multi-stages bagworm infested area. A notable improvement in coverage and control was observed during aerial spraying using drones compared to ground spraying. In 2013 until 2014, series of aerial sprayings were conducted to control bagworms at an oil palm plantation in Slim River, Perak using Aircraft Grumman Ag Cat model (Kamarudin et al., 2017). A lot of time was spent allocating and repositioning the aircraft at the end of each pass and transporting the aircraft from the loading site to the field. These time-consuming activities have been reduced when aerial spraying was conducted using drones. One of the critical problems for aerial spraying using aircraft is the requirement of a dedicated runway for take-off
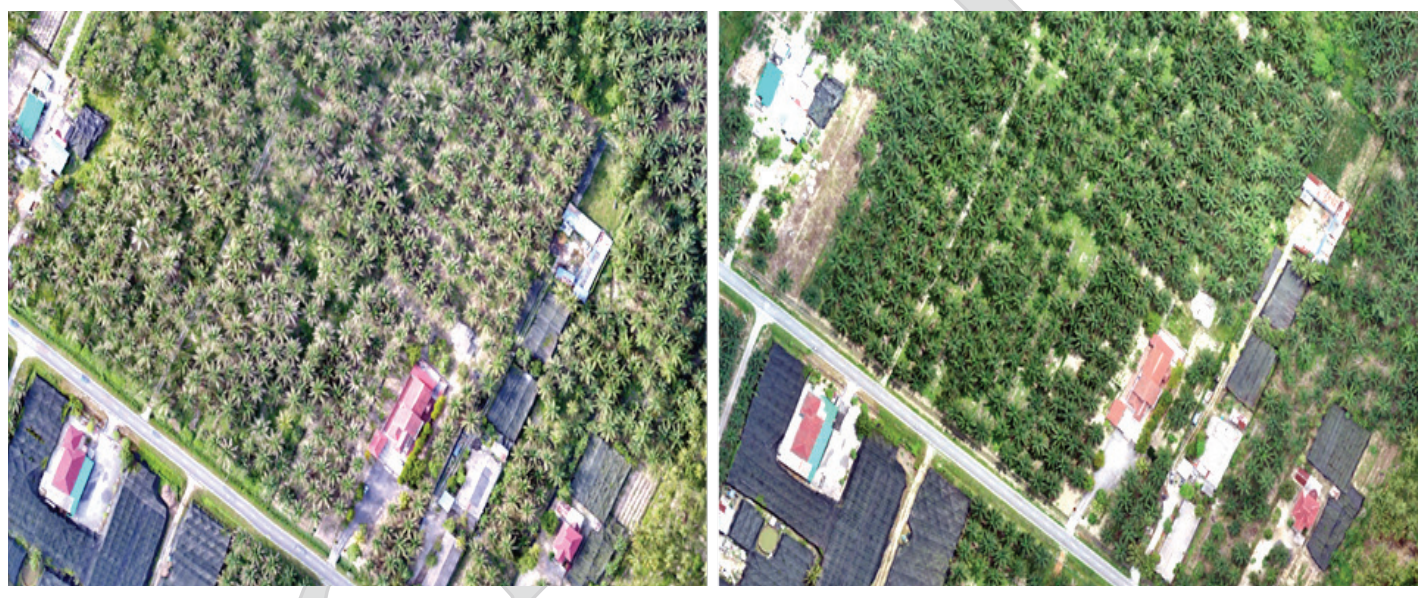

Figure 7. Severe infestation caused by M. plana before treatment in 2017 and two years after the treatment in 2019. (a) Before treatment in July 2017, and (b) after treatment in December 2019.
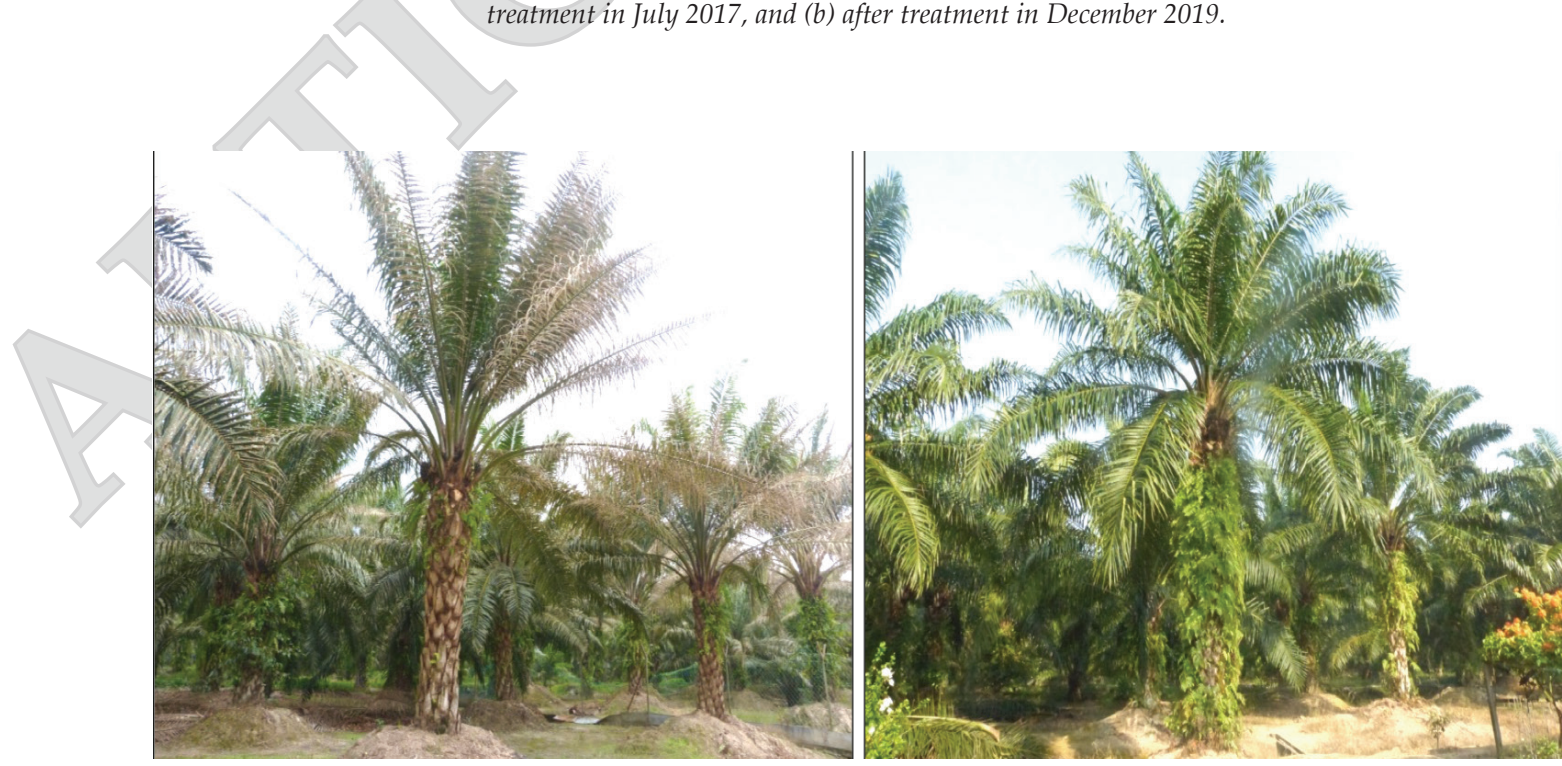

Figure 8. Ground observation on the recovery of the oil palm before and after the Bt drone spraying. (a) Before treatment in July 2017, and (b) after treatment in December 2019. 
and landing. It has been a struggle searching for the appropriate runway for the aircraft since the availability of airstrips in Malaysia for agricultural use is very lacking. The issue was somewhat resolved, by using drones as it can take off almost anywhere within the plantation without the timeconsuming search for a runway. It was found that drones are very beneficial for the rapid control of bagworms, especially in discreet hotspot areas. Compared to aircrafts, drones are highly efficient, low cost and environment friendly. The first-ever drone spraying conducted on oil palm to control bagworms depicted in this study had proved to be efficient in reducing the pest population. The right strategy to implement the drone spraying needs to be carefully planned according to the bagworm life stages.

Close monitoring of bagworm census, precise timing and follow-up aerial spraying were crucial strategies for controlling the multi-stage bagworm outbreak (Kamarudin et al., 2017). The average life cycle for M. plana from egg to adult takes about 103.5 days (Kok et al., 2011.). Hence, in strategising for the right control plan, the census data plays the utmost importance to determine when the treatment should begin. Areas with a multi-stage infestation may require follow-up treatments depending on the severity of infestation. In the first drone spraying, the number of larvae was successfully reduced, however, at $28 \mathrm{DAT}$, the high population of pupae had necessitate a follow-up treatment in the area. The pupa represents an inactive stage or resting mode for the bagworm, of which they will be able to ingest the delta-endotoxin from Bt (Mazmira et al., 2011). Thus, any control treatment carried out during the pupa stage will be ineffective and wasted. The pupal population that survived the drone spraying in the first round will eventually emerge as a new bagworm generation, and this explains the increase of larval population during the 0 DAT of the second round of drone spraying. With precise strategy and right implementations, the bagworm population was successfully reduced below the economic threshold level after the second aerial spray. The results thus, encourage the usage of drones as an essential tool for controlling at bagworm outbreak. Without proper treatment and the right strategy to contain the bagworm infestation, its population will gradually increase and over time will severely damage oil palm trees. A similar observation was recorded in the control plot, where the bagworm population would not simply vanish due to environmental factors. The population will keep increasing and will affect not only the area but also the neighbouring plantations. Thus, to ensure the bagworm population is maintained below the economic injury threshold level, close monitoring and consistent census are deemed very necessary. Leaving an infected area without control would lead to an outbreak, where consequently, significant effort and high operation costs will be required to control the pest.

Besides the right timing and strategy, the droplet deposits from the drone are also crucial in determining the success of the spraying. Droplet distribution will reflect the actual deposition level of the sprayed droplets (Guo et al., 2019). The flight velocity and the spraying height in this study was found to be appropriate for efficient control of bagworms in oil palm plantations. The droplets from the drone were distributed evenly, which enabled comprehensive coverage on the oil palm fronds for efficient control. This study agrees with the report by Guo et al. (2019), where they found that the flight height and velocity remarkably influenced the average deposition number of droplets. One of the factors that need to be further investigated is the effect of the vortex on droplet deposition during the drone spraying. Study on droplet distribution needs to be undertaken since the consistent application of the best-suited droplet size will contribute to better penetration of the crop canopy, decrease drift potential and evaporation, and add greater adherence of $\mathrm{Bt}$ to the leaves (Miranda et al., 2017). In this study, it was also found that the bagworm population was not significantly affected by rainfall. A series of rainfall exceeding $40 \mathrm{~mm}$ did not seem to cause a washout of Bt properties. Other studies have also shown that the bagworm populations had not correlated with weather changes (Ahya et al., 2012; Cheong et al., 2010; Ho et al., 2011).

The success of the drone spraying to control the bagworm population under the threshold level in the oil palm smallholding need to be adequately maintained. Bagworms can spread rapidly without proper control and monitoring. Bagworms are a recurring problem in oil palm plantations, and several factors have been identified as causes for the outbreaks. Factors such as strong wind, vehicles, animal and humans are reported as the spreading vector of bagworms (Cheong and Tey, 2012). The bagworm population in the area need to remain under the threshold level to avoid the risk of the recurring infestation since there are many cases where bagworm outbreaks often recur even when aerial spraying has been successfully conducted (Norman and Mazmira, 2019). Thus, the introduction of other biological control agents in the area holds significant importance. The planting of beneficial plants attracts beneficial insects which synergises with Bt aerial spraying to degrade the bagworm outbreak (Mazmira et al., 2011). Beneficial insects such as predators and parasitoids were found to be associated with the mortality of bagworms and naturally controlling the bagworm population in oil palm plantation (Basri, 1993; Cheong et al., 2010; Norman and Arshad, 2016). Planters must, therefore, 
seriously consider planting these beneficial plants like Cassia cobanensis, which provide honey from the leaf nodes as well as from the flowers (Norman et al., 2019). The researchers of this current study have advised the smallholders to initiate the planting of beneficial plants since the first drone aerial spraying was carried out in July 2017. The smallholders have collaborated well in maintaining the beneficial plants in their plantations, and the effects has been commendable. Synergism effects between the drone spraying using Bt and planting of beneficial plants have enabled the smallholders to avoid recurring infestations in the plantations and have successfully maintained the bagworm population under the economic threshold level even after two years since the drone spraying was first carried out. Additionally, the Bt aerial spray coupled with beneficial plants in the bagworm outbreak areas has led to a more efficient integrated pest management (IPM) which favourably necessitates novel drone applications.

\section{CONCLUSION}

In this study, the authors have documented the application of drone spraying of $\mathrm{Bt}$ based biopesticides for the control of bagworm outbreaks in oil palms. The efficacy of the drone spraying in reducing the bagworm outbreak under the economic threshold level at a severely infested area with multi-stages of bagworms after just two rounds of drone spraying significantly establishes a new tool for the IPM system. Application of biopesticides for bagworm control is frequently needed at a specific time and location for highly accurate site-specific management. The drone spraying is best suited for this purpose since the operation is undemanding with easy accessibility compared to agricultural aircraft. There is no requirement for a dedicated runway for drones and the logistic aspect of the operation are less consuming. With new applications being developed rapidly across many industries, including agriculture, there may be a sharp uptake of drone technology in the near future, especially in the oil palm industry. Drones are facilitating work in the agricultural field, especially in aerial spraying by reducing time and workforce. With the long term IPM strategy such as the planting of beneficial plants, the bagworm population can be maintained under the threshold for many years after completion of a successful drone spraying operation.

\section{ACKNOWLEDGEMENT}

The authors would like to thank the DirectorGeneral of MPOB for the permission to publish this article.

\section{REFERENCES}

Ahmad, M N; Ali, S R A; Masri, M M M and Asmawi, M Z (2015). Effect of Bacillus thuringiensis based-products on rats. J. Oil Palm Res., 27(1): 30-38.

Ahmad, M N; Ali, SR A; Masri, M M M and Wahid, M B (2012). Effect of Bt products, Lepcon-1, Bafog-1 (S) and Ecobac-1 (EC), against the oil palm pollinating weevil, Elaeidobius kamerunicus and beneficial insects associated with Cassia cobanensis. J. Oil Palm Res., 24: 1442-1447.

Ahmad, M N; Ali, S R A; Masri, M M M and Zolkarnain, N (2014). Lepcon-1, Bafog-1 (S) and Ecobac-1 (EC), Bacillus thuringiensis based-products are not toxic against freshwater fish, Tilapia nilotica. J. Oil Palm Res., 26(4): 317-320.

Ahya Mahadi, N; Muhamad and Azura Adam, N (2012). Relationship between bagworm Pteroma pendula Joannis (Lepidoptera: Psychidae) populations, parasitoids and weather parameters in oil palm plantation. J. Agricultural Science, 4(12): 1317. DOI: 10.5539 / jas.v4n12p13.

Amin, R I (2018). Pesawat ringan terhempas di Muadzam Shah. http://www.bharian.com.my/ berita/kes/2018/02/392870, accessed on

Attorney General's Chambers (2013). Declaration of dangerous pest 2013. Federal Government Gazette. PU(B) 468.

Basri, MW (1993). Life history, ecology and economic impact of the bagworm, Metisa plana Walker (Lepidoptera: Phychidae), on the oil palm. Elaeis guineensis Jacquin (Palmae). PhD thesis. University of Guelph.

Bernama (2017). MADA creates history with drone pesticide spray. https://www.malaymail.com/news/ malaysia/2017/04/01/mada-creates-history-with dronepesticide-spray-says-shabery/1347549, accessed on 1 April 2021.

Cheong, Y L and Tey, C C (2012). Understanding pest biology and behaviour for effective control of oil palm bagworms. Planter, 88(1039): 699-715.

Cheong, Y L; Sajap, A S; Hafidzi, M N; Omar, D and Abood, F (2010). Outbreaks of bagworms and their natural enemies in an oil palm, Elaeis guineensis, plantation at Hutan Melintang, Perak, Malaysia. J. Entomol., 7: 141-151. DOI: 10.3923/je.2010.141.151.

European Commision (2018). Digital Transformation Motor: Drones in Agriculture. p. 6. 
Giles, D K and Billing, R C (2015). Deployment and performance of a UAV for crop spraying. Chem. Eng. Trans., 44: 307-312.

Guo, S; Li, J; Yao, W; Zhan, Y; Li, Y and Shi, Y (2019). Distribution characteristics on droplet deposition of wind field vortex formed by multi-rotor UAV. PLoS ONE, 14: e0220024. DOI: 10.1371/journal. pone. 0220024

Hasber, S (2010). Evaluation of several chemical control approaches against bagworm, Metisa plana Walker (Lepidoptera: Psychidae) in FELDA oil palm plantations. MSc. thesis. Universiti Sains Malaysia.

Ho, C T; Yusof, I and Khoo, K C (2011). Infestation by the bagworms Metisa plana and Pteroma pendula for the period 1986-2000 in major oil palm estates managed by Golden Hope Plantation Berhad in Peninsular Malaysia. J. Oil Palm Res., 23(2): 10401050 .

Kamarudin, N; Ali, S R A; Masri, M M M; Ahmad, M N; Manan, C and Norman, K (2017). Controlling Metisa plana Walker (Lepidoptera: Psychidae) outbreak using Bacillus thuringiensis at an oil palm plantation in Slim River, Perak, Malaysia. J. Oil Palm Res., 29: 47-54.

Kamarulbaid, A M (2018). Guna Dron Musnah Ulat Bungkus. Utusan Malaysia. 26 March 2021.

Kok, C C; Eng, O K; Razak, A R and Arshad, A M (2011). Microstructure and life cycle of Metisa plana Walker (Lepidoptera: Psychidae). J. Sustain. Sci. Manag., 6: 51-59.

Mat Su, A S; Yahya, A; Mazlan, N and Ahmad Hamdani, M S (2018). Evaluation of the spraying dispersion and uniformity using drone in rice field application. MSAE Conference, Serdang, Selangor. 7-8 February 2018.

Mazmira, M; Ramlah, S; Najib, M; Norman, K; Kushairi, A and Wahid, M B (2011). Pest management of bagworm in Southern Perak by aerial spraying with Bacillus thuringiensis. Oil Palm Bulletin, 63: 24-33.

Miranda, P S; Monteiro, N; Pradeep, V; Dsouza, R and Fernandes, G H (2017). Farmer friendly drone. Int. J. Internet of Things, 6: 56-61. DOI: $10.5923 / \mathrm{j}$. ijit.20170602.10.

Rao Mogili, U M and Deepak, B B V L (2018). Review on application of drone systems in precision agriculture. Procedia Computer Science, 33: 502-509.
MPOB (2016). Standard Operating Procedure (SOP) Guidelines for Bagworm Control. MPOB, Bangi. 41 pp.

Norasma, C Y N; Abu Sari, M Y; Fadzilah, M A; Ismail, M R; Omar, M; H Zulkarami, B; Hassim, Y M M and Tarmidi, Z (2018). Rice crop monitoring using multirotor UAV and RGB digital camera at early stage of growth. IOP Conf. Ser.: Earth Environ. Sci., 169: 012095.

Norman, K; Basri, M W; Ramle, M and Ramlah, A A $S$ (2004). Bagworms, rhinocerous beetle and nettle caterpillars - Biology, life cycle and control on oil palms in Malaysia. Proc. Industrial Conf. Pests and Diseases of Importance to the Oil Palm Industry. p. 96116.

Norman, K and Arshad, O (2016). Diversity and activity of insect natural enemies of the bagworm (Lepidoptera: Psychidae) within an oil palm plantation in Perak, Malaysia. J. Oil Palm Res., 28: 296-307. DOI: 10.21894 / jopr.2803.06.

Norman, K and Mazmira, M M M (2019). Industrywide efforts in circumventing the scourge of bagworm infestation in Malaysia - What have gone wrong and what should be done? Planter, 95(1118): 321-333.

Norman, K; Seman, I A and Masri, M M M (2019). Prospects in sustainable control of oil palm pests and diseases through the enhancement of ecosystem services - The way forward. J. Oil Palm Res., 31: 381-393.

Ramlah, A A S; Najib, M A and Mazmira, M M M (2011). Method of producing microbial insecticide. Malaysian Patent Application PI2011000307.

Ramlah, A A S; Norman, K; Basri, M W; Najib, M A; Mohd Mazmira, M M and Kushairi, A (2007a). Manual Pengurusan Bersepadu Ulat Bungkus di Ladang Sawit. MPOB, Bangi. 15 pp.

Ramlah, A A S; Norman, K; Basri, M W; Najib, M A; Mohd Mazmira, M M and Kushairi, A (2007b). Sistem Pengurusan Perosak Bersepadu bagi Kawalan Ulat Bungkus di Ladang Sawit. MPOB, Bangi. 28 pp.

Ramlah, A A S and Basri, M W (1997). A local Bacillus thuringiensis SRBT1 with potential for controlling Metisa plana (Wlk). J. Oil Palm Res., 9(1): 34-45.

Sundaram, K M S; de Groot, P and Sundaram, A (1987). Permethrin deposits and airborne concentrations downwind from a single swath application using a back pack mist blower. J. Environ. Sci. Health B, 22(2): 171-193. 
Tey, C C and Cheong, Y L (2013). Challenges in integrated pest management (IPM). Proc. of $10^{\text {th }}$ NATSEM 2013 - Confronting Management Challenges in the Oil Palm Industry. Incorporated Society of Planters, Kuala Lumpur. p. 117-127.

Theriault, R; Salyani, M and Panneton, B (2001). Spray distribution and recovery in citrus application with a recycling sprayer. Trans. ASAE, 44(5): 10831088 .

Thomas, G (2017). Treat bagworm early, MPOB. Retrieved from https://www.thestar.com.my/ opinion / letters / 2017 / 05 / 30 / treat-bagwormsearly-mpob, accessed on 30 May 2020.
Wood, B J (2002). Pest control in Malaysia's perennial crops: A half century perspective tracking the pathway to integrated pest management. Integr. Pest Manag. Rev., 7: 173-190.

Wood, B J and Kamarudin, N (2019). Bagworm (Lepidoptera: Psychidae) infestation in the centennial of the Malaysian oil palm industry - A review of causes and control. J. Oil Palm Res., 31: $364-380$.

Zhang, D Y; Lan, Y B; Chen, L P; Wang, X and Liang, D (2018). Current status and future trends of agricultural aerial spraying technology in China. Trans. Chin. Soc. Agric. Machinery, 45(10): 53-59. 